\title{
Emergency abdominal surgery in a patient anticoagulated with dabigatran
}

\author{
Jonas Paul DeMuro, M.D.
}

Department of Surgery, Division of Trauma \& Critical Care, Winthrop University Hospital, Mineola, New York, USA

\begin{abstract}
Dabigatran is a newer oral anticoagulant, indicated for chronic atrial fibrillation anticoagulation. Experience with an emergent laparotomy in a patient on dabigatran is presented. Difficulties of this medication and strategies to deal with the coagulopathy from this direct thrombin inhibitor are described.
\end{abstract}

Key words: Coagulopathy, dabigatran, direct thrombin inhibitor, perioperative bleeding, reversal of coagulopathy.

\section{INTRODUCTION}

Dabigatran (Pradaxa, Boehringer Ingelheim Pharma) is a direct thrombin inhibitor. It is a potent anticoagulant that is prescribed for chronic atrial fibrillation. ${ }^{[1]}$ Over a million prescriptions were written in the first 10 months of its approv$\mathrm{al}^{\left[{ }^{[2]}\right.}$ with the benefit of no monitoring of blood work. Ideally, dabigatran should be stopped several days in advance of any invasive procedures; however, when emergency surgery is indicated, this presents a severe challenge. The experience with such a case is related herein, and is believed to be the first published case of emergency abdominal surgery in a patient on dabigatran.

\section{CASE REPORT}

A 69-year-old female presented to the Emergency Department with a one-day history of nausea, vomiting, and obstipation. Her medical history was significant for morbid obesity ( $165 \mathrm{~kg}$ ), hypertension, atrial fibrillation, hypothyroidism, and oxalate nephropathy. The surgical history included a jejunoileal bypass almost 40 years prior, with a subsequent revision one year later, and an incisional hernia repair 30 years prior. Her medications on admission included calcium, levothyrox-

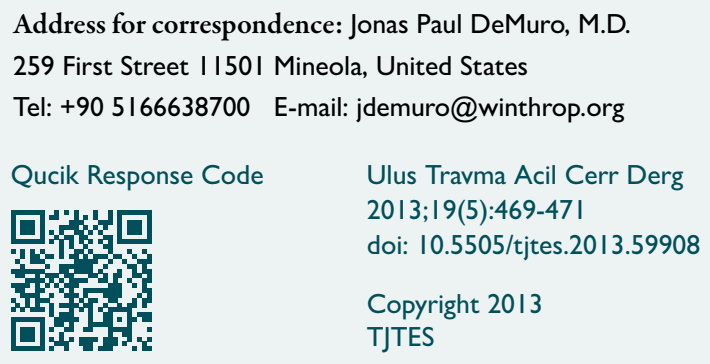

ine, losartan, and dabigatran $75 \mathrm{mg}$ orally two times daily (adjusted for decreased renal function).

On admission, her vital signs were normal and she was afebrile. The physical exam was significant for a moderately distended abdomen with tenderness in the left upper quadrant, but no peritoneal signs. Her admission white blood cell count was $16.2 \mathrm{~K} / \mu \mathrm{L}$, with a hematocrit of $42.3 \%$ and a platelet count of $27 \mathrm{I} \mathrm{K} / \mu \mathrm{L}$. Admission chemistries showed bicarb 10, blood urea nitrogen $33 \mathrm{mg} / \mathrm{dl}$, creatinine $1.6 \mathrm{mg} / \mathrm{dl}$, and glucose $218 \mathrm{mg} / \mathrm{dl}$, with an anion gap of 20 . The coagulation profile showed a prothrombin time of 14.2 seconds, international normalized ratio of 1.29 , and a partial thromboplastin time of 44.9 seconds. An arterial blood gas had a $\mathrm{pH}$ of 7.21 and a base excess of - II.6. The EKG showed atrial fibrillation at a heart rate of 87 beats per minute.

Due to the clinical obstruction and the chronic creatinine elevation, a noncontrast computerized tomography (CT) was performed. The study showed a complete small bowel obstruction with pneumatosis and extraluminal air (Fig. Ia). The maximal diameter of the small bowel was $10.5 \mathrm{~cm}$.

After emergency consultation with a hematologist, despite the normal coagulation profile, 2 units of fresh frozen plasma were quickly transfused in preparation for the exploratory laparotomy, following published recommendations. ${ }^{[3]}$ In the operating room, the abdomen was entered via a midline incision, and on exploration, a volvulus of the small bowel was found with pneumatosis of the wall (Fig. Ib). The previously bypassed small and large bowel had twisted around each other, requiring resection of both due to vascular compromise. The resections were done with a vascular loaded stapler for the bowel, and the mesentery of the bowel was divided using the LigaSure device (Covidien). 

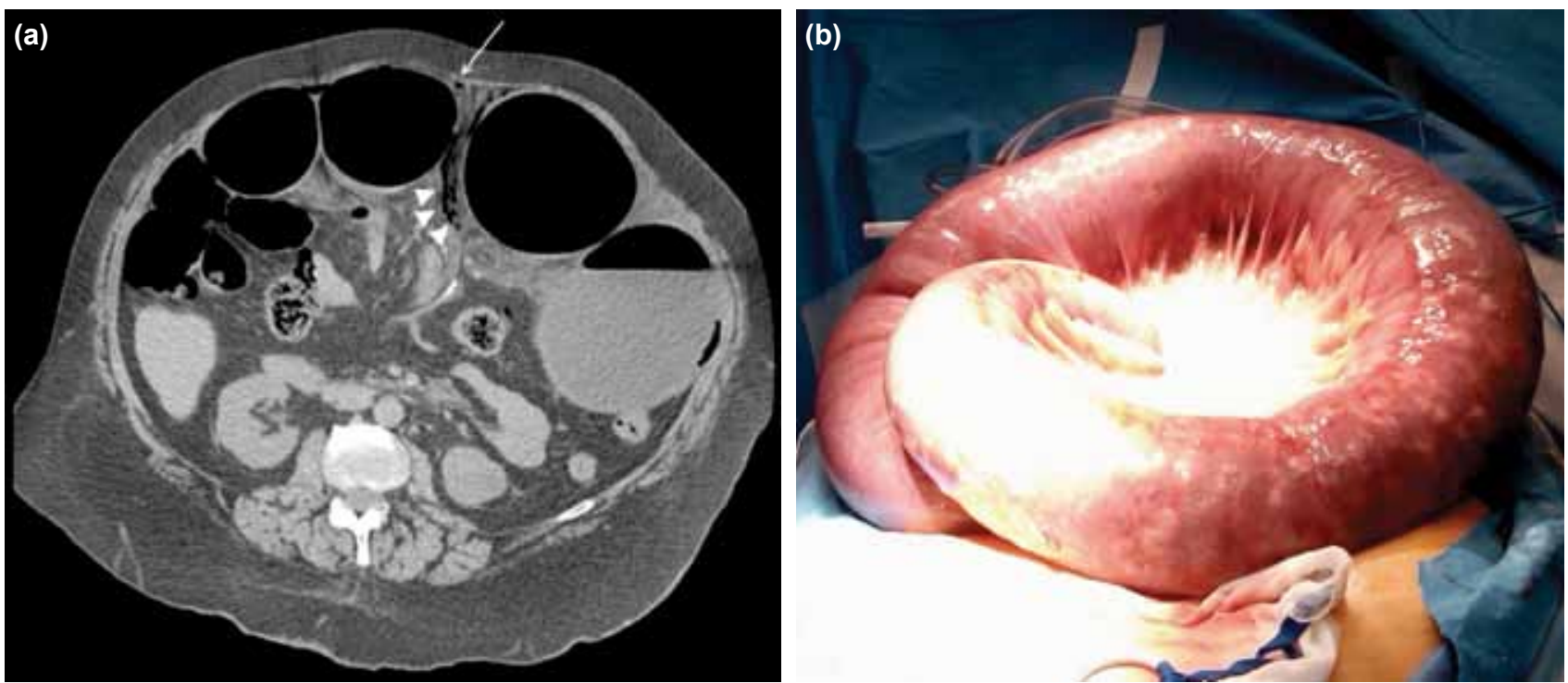

Figure 1. (a) Noncontrast CT of the abdomen and pelvis revealed a small bowel obstruction secondary to a small bowel volvulus. Note the pneumatosis in the bowel lumen (three white triangles) and the small amount of extraluminal air present (single white arrow). (b) Intraoperative image shows the significantly dilated small bowel with pneumatosis.

Despite these efforts, the hemostasis of the mesentery was inadequate, and did not respond to conventional measures, including electrocautery, additional LigaSure applications, suture ligation, and clips. With active external rewarming, the patient remained normothermic throughout the procedure, although the acidosis worsened with an intraoperative $\mathrm{pH}$ that dropped to 7.14. The bleeding was not arterial, but diffuse, coagulopathic, and increasing, when the decision was made to apply damage control techniques, foregoing any attempt at an anastomosis. A temporary abdominal closure device (AbVAC) was utilized. The total estimated blood loss for the procedure was $1200 \mathrm{cc}$.

In the Surgical Intensive Care Unit, the platelets and coagulation profile remained normal, but the drainage from the abdomen was 500 to $600 \mathrm{cc}$ every 12 hours. This continued over the next 72 hours, and the patient was reexplored in the operating room, and another $600 \mathrm{cc}$ of blood was lost from coagulopathic bleeding with no other interventions other than for hemostasis. When the patient was brought back on postoperative day 5 from the original surgery, she was finally no longer coagulopathic.

\section{DISCUSSION}

Dabigatran, a direct thrombin inhibitor, is a potent anticoagulant. Standard blood coagulation studies reassure rather than reveal how coagulopathic a patient is on this medication, and they should not be used to determine the anticoagulation effects of any direct thrombin inhibitor. ${ }^{[4]}$ Dabigatran can be monitored with an ecarin clotting time (ECT), ${ }^{[5]}$ but this is not readily available in most institutions. The long 14-17-hour half-life of dabigatran ${ }^{[6]}$ contributes to a prolonged potential for bleeding when emergent surgery is needed.
There is limited experience with reversal of dabigatran coagulopathy. As the majority of dabigatran is not bound to plasma proteins, acute hemodialysis can be used in severe cases to reverse coagulopathy. ${ }^{[7]}$ Prothrombin complex concentrate (PCC), used in an experimental model of healthy volunteers, did not reverse the effects of dabigatran. ${ }^{[8]}$ In the case presented above, the author does not believe the fresh frozen plasma that was administered had any clinical effect on the coagulopathy of the patient. There is preliminary data that recombinant factor VIla may partially reverse another direct thrombin inhibitor. ${ }^{[9]}$ Finally, there is one isolated report of a multifactorial approach with hemodialysis, fresh frozen plasma and recombinant factor Vlla used successfully to reverse another direct thrombin inhibitor (bivalrudin) after cardiac surgery. ${ }^{[10]}$

Ideally, surgery should be delayed for several days in the setting of a patient on dabigatran. This case illustrates the hazards of an operation in a patient on this medication, and based on the author's literature search, it is the first reported case of an emergent laparotomy in a patient on dabigatran. In general, only the most emergent cases in patients on dabigatran should be undertaken, realizing the high risk of operating on such a severely coagulopathic patient. Reversal of the dabigatran will be incomplete at best in the immediate perioperative period, and should be multimodal including hemodialysis. Early and liberal use of damage control operative techniques is advisable for those patients on dabigatran that require an immediate abdominal operation.

\section{Conflict of interest: None declared.}

\section{REFERENCES}

1. Gutierrez C, Blanchard DG. Atrial fibrillation: diagnosis and treatment. 
Am Fam Physician 2011;83:61-8.

2. FDA Drug Safety Communication: Safety Review of post-market reports of serious bleeding events with the anticoagulant Pradaxa (dabigatran etexilate mesylate), available at, http://www.fda.gov/drugs/drugsafety/ucm282724.htm, accessed April 4th, 2012.

3. van Ryn J, Stangier J, Haertter S, Liesenfeld KH, Wienen W, Feuring M, et al. Dabigatran etexilate--a novel, reversible, oral direct thrombin inhibitor: interpretation of coagulation assays and reversal of anticoagulant activity. Thromb Haemost 2010;103:1116-27.

4. Di Nisio M, Middeldorp S, Büller HR. Direct thrombin inhibitors. N Engl J Med 2005;353:1028-40.

5. Schaden E, Kozek-Langenecker SA. Direct thrombin inhibitors: pharmacology and application in intensive care medicine. Intensive Care Med 2010;36:1127-37.

6. Tsiara S, Pappas K, Boutsis D, Laffan M. New oral anticoagulants: should they replace heparins and warfarin? Hellenic J Cardiol 2011;52:52-67.
7. Schulman S, Crowther MA. How I treat with anticoagulants in 2012: new and old anticoagulants, and when and how to switch. Blood 2012;119:3016-23.

8. Eerenberg ES, Kamphuisen PW, Sijpkens MK, Meijers JC, Buller HR, Levi M. Reversal of rivaroxaban and dabigatran by prothrombin complex concentrate: a randomized, placebo-controlled, crossover study in healthy subjects. Circulation 2011;124:1573-9.

9. Wolzt M, Levi M, Sarich TC, Boström SL, Eriksson UG, ErikssonLepkowska M, et al. Effect of recombinant factor VIIa on melagatran-induced inhibition of thrombin generation and platelet activation in healthy volunteers. Thromb Haemost 2004;91:1090-6.

10. Stratmann G, deSilva AM, Tseng EE, Hambleton J, Balea M, Romo AJ, et al. Reversal of direct thrombin inhibition after cardiopulmonary bypass in a patient with heparin-induced thrombocytopenia. Anesth Analg 2004;98:1635-9.

\section{OLGU SUNUMU - ÖZET}

\section{Dabigatran ile antikoagüle edilen hastada acil karın cerrahisi Dr. Jonas Paul DeMuro \\ Winthrop Üniversitesi Hastanesi, Cerrahi Bölümü, Travma ve Acil Kliniği, Mineola, New York, ABD}

Dabigatran, kronik atriyum fibrilasyonunda antikoagülasyon için kullanılan yeni bir pıhtı önleyici ilaçtır. Dabitagran alan bir hastada acil laparotomi deneyimi sunulmaktadır. Bu ilaç tedavisinin zorlukları ve bu direkt trombin inhibitörü nedeniyle oluşan koagülopati ile başa çıkma stratejileri tanımlanmışır. Anahtar sözcükler: Koagülopati, dabigatran, direkt trombin inhibitörü, perioperatif kanama, koagülopati sürecinin çevrimi.

Ulus Travma Acil Cerr Derg 20 I3; I9(5):469-47। doi: 10.5505/tjtes.20।3.59908 